\title{
Offences and Procedures in the Iranian and United State Capital Markets*
}

\author{
Mahdi Ashourzadeh Chakusari' ${ }^{1}$, Mohsen Shekarchi Zadeh², \\ Gholamhossein Masoud ${ }^{3}$ \\ Islamic Azad University, Iran \\ $\underline{10.15408 / j \text { ch.v8i2.15491 }}$
}

\begin{abstract}
Economic development in today's societies has provided the bad for the development of economic offences and consequently. Today, one of the simplest and sometimes safest ways to make money can be an investment in the field of the stock exchange. Investing personal money through investment in the economic cycle has helped the economic cycle a lot and has prevented inflation and stagnation in this cycle and on the other hand. It has provided conditions for some offences. The stock exchange can be a good platform to commit classic offences such as the betrayal of trust, theft and fraud and also can ease offences such as different types of fraud, cybercrimes and so on. Therefore, the governments have always thought about controlling and protecting the capital and the investors to prevent the chaos in the stock exchange and consequently, the economy of the society. The actions of activists in the capital market, which are against the principles and regulations of the market can be classified into 3 groups: 1 . Regulative offences 2 . Disputes 3. Offences. The occurrence of any of these acts is inevitable and can pave the way for distort of regulation and the security of governor on the investment activities of the states. Therefore, this study has attempted to consider the abovementioned issues as much as possible in Iran and US countries. Then, the study tends to analyze and investigate the supervising officials and tends, at last, to present types of lawsuits and procedures for them in the field of the stock exchange.

Keywords: Stock Exchange, Exchange Crimes, Exchange Offences, Exchange Offence Investigation
\end{abstract}

\footnotetext{
* Received: January 19, 2020, revised: March 21, 2020, accepted: July 21, 2020, Published: August $4,2020$.

1 Department of Law, Najafabad Branch, Islamic Azad University, Najafabad, Iran Email: mahdi.ashourzadeh@gmail.com 1 orcid.org/0000-0001-9960-5103

2 Department of Law, Najafabad Branch, Islamic Azad University, Najafabad, Iran. Email: Mohsen.shekarchi@gmail.com iD orcid.org/0000-0002-5292-3558

3 Department of Law, Najafabad Branch, Islamic Azad University, Najafabad, Iran. Email: Gh.masoud@gmail.com iD orcid.org/0000-0003-0541-0159
}

Corresponding Author: Email: Mohsen.shekarchi@gmail.com iD orcid.org/0000-0002-5292-3558 


\title{
Pelanggaran dan Prosedur di Pasar Modal Iran dan Amerika Serikat
}

\begin{abstract}
Abstrak
Perkembangan ekonomi di masyarakat saat ini telah memberikan dampak buruk bagi perkembangan pelanggaran ekonomi dan akibatnya. Saat ini, salah satu cara paling sederhana dan terkadang teraman untuk menghasilkan uang adalah dengan berinvestasi di bidang bursa saham. Menginvestasikan uang pribadi melalui investasi dalam siklus ekonomi telah banyak membantu siklus ekonomi dan telah mencegah inflasi dan stagnasi dalam siklus ini dan sebaliknya. Ini telah memberikan kondisi untuk beberapa pelanggaran. Bursa saham dapat menjadi platform yang baik untuk melakukan pelanggaran klasik seperti pengkhianatan kepercayaan, pencurian dan penipuan dan juga dapat meringankan pelanggaran seperti berbagai jenis penipuan, kejahatan dunia maya dan sebagainya. Oleh karena itu, pemerintah selalu memikirkan untuk mengontrol dan melindungi modal dan investor untuk mencegah terjadinya kekacauan di bursa efek dan akibatnya, perekonomian masyarakat. Tindakan para pegiat pasar modal yang bertentangan dengan prinsip dan ketentuan pasar dapat diklasifikasikan menjadi 3 kelompok: 1. Tindak pidana regulasi 2. Sengketa 3. Pelanggaran. Terjadinya salah satu tindakan ini tidak dapat dihindari dan dapat membuka jalan bagi distorsi regulasi dan keamanan gubernur atas kegiatan investasi negara. Oleh karena itu, studi ini berusaha untuk sedapat mungkin mempertimbangkan masalah-masalah tersebut di atas di negara-negara Iran dan AS. Kemudian, studi ini cenderung menganalisis dan menyelidiki aparat pengawas, dan pada akhirnya cenderung menyajikan jenis-jenis tuntutan dan tata cara di bidang bursa.
\end{abstract}

Kata Kunci: bursa efek, kejahatan bursa, delik pertukaran, investigasi tindak pidana bursa

\section{Правонарушения и процедуры на рынке капиталов в Иране и США}

\begin{abstract}
Аннотация
Текущее экономическое развитие в обществе негативно сказалось на развитии экономических нарушений и их последствий. Сегодня один из самых простых и иногда самых безопасных способов заработать деньги - это инвестировать в фондовую биржу. Вложение личных денег посредством инвестирования в экономические циклы помогло экономическим циклам и предотвратило инфляцию и стагнацию в них, и наоборот. Это создало условия для совершения нескольких преступлений. Фондовая биржа может быть хорошей платформой для совершения классических преступлений, таких как обман доверия, кража и мошенничество, а также может смягчать такие преступления, как различные виды мошенничества, киберпреступность и т. д. Поэтому правительство всегда думает о контроле и защите капитала и инвесторов, чтобы предотвратить хаос на фондовой бирже и, как следствие, защитить народную экономику. Действия участников рынка капиталов, противоречащие рыночным принципам и нормам, можно разделить на 3 группы: 1. Нормативные преступления 2. Споры 3. Нарушения. Совершение одного из этих действий неизбежно и может приводить к регулирующим и безопасным действиям губернатора для инвестиционной деятельности страны. Таким образом, данное исследование направлено на то, чтобы как можно больше рассмотреть эти проблемы в Иране и США. Затем в этом исследовании анализируется и исследуется надзорный аппарат, и, наконец, представлены типы требований и процедуры в области фондовой биржи. Ключевые слова: Фондовая биржа, биржевое преступление, обменное преступление, расследование биржевого преступления.
\end{abstract}




\section{A. INTRODUCTION}

Capital market (Langerudi \& Jafar, 2003; Kadkhodaei, 1999) ${ }^{4}$ is such a market, in which different assets of the society can be transacted. The prosperity and development of this market is in line with the mechanisms of just solution of the disputes caused by activity in this market. Exchange offences are types of offences against state economic system and the impacts of the offences on manufacturing, commerce and investment is clear. This type of offences can generally reduce participation of investors in stock exchange because of creating information injustice and possibility of gaining higher revenue for some people and can damage national economy through this. In all human societies from the beginning until now, the criminal cycle has been formed of 3 stages and is aimed at preserving social life of people and life of social people.

The first stage is making regulations and legislation. The second step is violation of the regulation (committing crime) and the third step is social reaction against the act or omission of the act of violating law (mainly punishment and sometimes, corrective and protective measures). In view of economic experts, stock exchange is the thermometer of each country and major part of the offences is relevant to the field of stock exchange. Increasing importance of stock exchange in the economic structure of different states and relevant complications and the economic capability of that have made the said market one of the most important beds for committing white-collar crimes.

As majority of exchange offenders are white-collar offenders with high IQ and high capabilities in this field and as majority of them are members of board of directors and have strong information rent; committing crimes by this class can impose distrust and inefficiency on the capital market and can consequently cause damage of economic system. On the other hand, a few articles and works have been conducted in field of exchange offences and relevant to legal and economic field and other economic crimes. One reason for this can be in familiarity of criminal lawyers with this specialized field. The recent studies in field of stock exchange are mostly relevant to financial management. This study expects several difficulties and problems such as lack of access to true

\footnotetext{
${ }^{4}$ Capital market is same stock exchange (stock market) used in both Iran and US countries. The term "exchange" is a French word, which has been used in dictionaries as packet-shaped bag, dealing market or shop and sometimes as the place for transaction. Some people also believe that the term "exchange" is attributed to one of Belgian bankers in Brudes called Vander Burse). in general terms, exchange can be applied for the place, where some part of bonds or unified commodities are priced with certain regulation and then transactions can be done on them
} 
information on behalf of exchange organization or executive costs and things like this; although there would be no serious problem in way of doing this study.

\section{B. METHODS}

This research applied a normative juridical method or library research through secondary material. Supplementary to this, this paper use a statue approach, a conceptual approach, as well as a comparative approach between Iran country and USA country. Meanwhile, the data resources as a reference for this research are utilized through a literature study.

\section{RESULT AND DISCUSSION}

\section{Law of USA and Iran Countries}

In this section, the regulations in field of exchange are shortly discussed at the first. Then, more information is provided to complete the discussion.

\section{a. Iran}

In article 35 of Securities Exchange Act of 2005 and article 17 of executive code of conduct of same act; board of directors is appointed as the authority to handle the regulative offences of market activists. The instruction of article 35 (approved in 2008 by the board of stock exchange) has said in article 2 that any kind of act or omission leading to violation of regulations relevant to capital market such as exchange regulation, council regulations, exchange organization or self-regulator formations; can be regarded as offence (Noorani \& Eyvazi, 2016).

\section{b. USA}

Using alternative methods for dispute solution in US law is not new approach and has longstanding history. Despite criticism and concern over the use of dispute resolution techniques and especially arbitration because of inattentiveness to law; special points such as easy and fast procedure has increased the use of this method. To execute the federal regulations dominated on the stock exchange and supervision on capital market in federal level; whereby Securities Exchange Act of 1934, an institution called Securities and Exchange Commission (SEC) was established. Executive part of the commission is charged to make investigation and exploration of offences of entities in field of exchange regulations and presenting appropriate civil or criminal lawsuit in 
federal court or qualified authorities against the offenders. Exchange law has allocated the authority of investigations on the violation of the regulations or relevant bylaw to the commission and has also allocated the request for criminal prosecution of offenders to the Attorney General (Securities Exchange Act of 1934, pp. Paragraph b, section 2).

\section{First: Legislative institutes of US financial industry}

Securities Exchange Commission (SEC): the Securities Exchange Commission (SEC) has been established based on the Securities Exchange Act of 1934 and its activity is independent from the US government. The commission is one of the most comprehensive and powerful organizations to enforce the exchange regulations of federal government and is also responsible for legislation for majority of exchange industries. Supervisory domain of the commission includes stock exchanges, markets and Trading Option Contract Stock Exchanges, electronic exchanges and investment consultants.

Financial Industry Regulatory Authority (FINRA): FINRA is a selfregulated and non-governmental institute established in 2007 from integration of National Association of Securities Traders and supervising units of New York Stock Exchange. The institution is appointed for protecting the rights of US investors and to make sure of accuracy of operations of the broker-dealer industry by the congress. The responsibility of FINRA is protecting the investors and capital market through regulating effective laws for the broker-dealers.

Regulating and enforcing the regulations dominated on activities of more than 3800 broker-dealer, along with 634000 brokers, monitoring the companied to observe the regulations, protecting market transparency and training investors are other responsibilities of FINRA. The regulations of the institute play key role in US financial system and protection of investors. Moreover, the systems and technologies used in this association can be one of the useful and significant capabilities, through that the stock market and broker firms can be monitored and controlled effectively. The cheatings and potential risks can be discovered and investors can be informed about everything through useful instruments.

\section{Second: Role of financial institutes in market monitoring}

FINRA association, along with Securities Exchange Commission (SEC), take activities of about 20 stock exchanges and Depository Trust \& Clearing Corporation (DTCC) daily, so that they can make sure that the orders of clients can be processed effectively. This can enhance and reinforce the financial markets 
and can ultimately cause protection of rights of millions of investors. Monitoring and supervision is the main and the early task of FINRA and it has legal requirement to do this. On the other hand, the SEC is itself legislative institute, which is mainly responsible for protection of investor rights in stock exchanges, preservation of market integration and facilitation of finance affairs.

The association takes wide range plans including executive orders, inspections and monitoring programs to achieve this goal. In regard with market monitoring, SEC is in tight relationship with self-regulated institutes and has also supervision on the monitoring programs relevant to self-regulated institutes. In regard with monitoring the FINRA activities, an association called The FINRA and Securities Industry Oversight (FSIO) is established in place of SEC association.

\section{Types of Lawsuit of Capital Market}

In general, the activities of market activists against the market regulations can be classified in 3 groups (Mehrabi Pour, 2009, p. 22): violation of regulation, disputes and offences. As a result of occurrence of each item, damage is imposed on the regulation and safety of the capital market and based on the sensitivities and necessities of this market, different authorities are predicted to handle the offences and disputes.

\section{a. Disputes}

In accordance with article 36 of Market Law, the disputes among brokers, Marketers, Brokers, Traders, Investors Consultants, Publishers, Investors and other beneficiaries caused by theor professional activity would be handled by the arbitration board in case of lack of compromise. Article 2 of Instructions of the Securities and Exchange Brokers Association has also mentioned in regard with completing the provisions of the abovementioned article: "in order to make conciliation in the dispute caused by professional activity of brokers, brokerdealers, marketers with other people; a committee was established under the title of Conciliation Committee at Stock Exchange Brokers (called association in this article)" (Karimi, 2017).

In US law, no special authority is predicted to deal with the legal lawsuits caused by the securities transactions. Along with litigation done traditionally in the court, alternative methods are existed that are used increasingly to solve the disputes of US capital market. Mediation and arbitration are two legal and efficient instruments to solve the disputes in capital market. 


\section{First: The Organization and Structure of the Conciliation Committee (Dispute Settlement Body)}

In accordance with article 3 of instruction, conciliation committee is formed of 3 members as follows: a representative from beneficiary exchange due to the subject of dispute based on order of board of directors of that exchange, a representative of association on behalf of the association and a representative from the organization on behalf of the board of directors. The beneficiary exchange, association and the organization, in addition to the major representative, introduce reserve member, so that that person can participate in the sessions of conciliation committee in case of absence of the major member. The conditions of reserve members, similar to major members (Instructions of the Securities and Exchange Brokers Association Committee, p. Article 3 and notes 1 and 2), and the duration of mission of both members can be two years and there is no problem for reappointing them (Instructions of the Securities and Exchange Brokers Association Committee, p. note of article 3).

\section{Second: The procedure of disputes in associations}

Procedure in conciliation associations includes formalities, which should be enforced by the disputing parties and administrative authorities and one of the items is regulation of petition and submitting that to the association. Conciliation committee includes secretariat deployed in the place of association and takes the preliminaries of procedure such as getting the complaints, making case, setting appointment, inviting all members, making sessions and setting the agenda and conciliation and no-conciliation certifications (Instructions of the Securities and Exchange Brokers Association Committee, p. Article 6). Conciliation committee secretariat announces the subject of lawsuit after getting the complaint, along with the proofs within 3 workdays. A 10-day deadline is also determined to get the reply. After expiration of the said deadline, in case of getting the reply, the relevant reply is notified to the plaintiff within 3 days (Instructions of the Securities and Exchange Brokers Association Committee, p. Article 7 ).

\section{b. Offences}

In accordance with article 35 of the Market Law, procedure includes the disciplinary offences of brokers, brokers-dealers, marketers, publishers and exchange members (except for board of directors) or exchange board of directors. 
The issues order can be appealed in the organization and the order issued by the organization is final and binding.

In enforcement of article 35, the exchange board is charged to handle the offences of the said entities based on the relevant bylaw and the instruction announced by the organization. In accordance with article 17 of the Market Bylaw, a copy of the votes issued on the regulation offences shall be submitted to the organization maximum within 3 days. In enforcement of article 35 of market law and articles 17 and 18 of the bylaw, relevant instruction was approved by exchange board in 2008.

In addition to the mentioned instruction, article 18 of the market bylaw says that procedure of CEO offences and the exchange board and elements of other self-regulated organization would be in limit of authority of the exchange board and elements of other organizations are in limit of authority of the organization board. In enforcement of this article, an instruction was approved by the exchange supreme council to handle the offences of CEOs, senior directors, exchange board members and elements of self-regulated organizations. According to the instruction, procedure committee was formed to take the preliminary investigations and issuance of vote. The decisions of the committee for procedure of the board or the exchange board shall be notified in determined deadline.

If the offences committed causes suspension of the permission of the offender in view of the committee, the committee is charged to refer the case to the organization board for procedure to leave comment and issue competent vote after getting required procedure. In accordance with the regulations, the issued vote is final and binding; otherwise, (if the committed offence causes cancellation or suspension of the permission of the offender in view of the committee) the exchange board is qualified to be responsible for the case procedure. With detailed analysis of the instruction and comparing it with the criminal procedure regulations, it is clear that the authors of the instruction have tended to create an authority in the capital market just like the court in criminal system. only those votes could be enforced in the board that the sanction for them was other than cancellation or suspension of the permission.

\section{First: Amendment of the instructions for procedure of offences committed by entities}

The exchange board approved the instruction for procedure of offences committed by entities subject to the article 35 of exchange law and other entities under supervision in enforcement of article 35 of Exchange Law of Islamic 
Republic of Iran approved in December 2005 and article 17 and 15 of the bylaw of the said act. In 2011, the instruction was amended in enforcement of note 5 of article 1 of the said act and to determine the procedure of offences of entities subject to article 14 of Law on the Development of New Financial Instruments and Institutions in order to facilitate enforcement of general policies of article 44 of the Constitution.

In accordance with the amended instruction, the elements forming the offences were determined and the examples of offences and appropriate punishments for them were analyzed based on the bylaw on procedure of broker offences. In accordance with the said instruction, based on membership or lack of membership of the offender in self-regulated organization or based on the determined punishments based on offender authority (the offender is subject of article 3 of the instructions and article 18 of the market by law or not), the procedure authorities would be appointed. The procedure authorities are offence procedure committee, relevant self-regulated organization, offence procedure board and organization board.

An important issue here is: based on the regulations of amended instruction, the procedure committee determined the sanction for the offence based on the preliminary investigations of the existing documents in the case and refers the case to qualified authorities based on the certain punishment. Another point here is as follows: the instruction has employed the term "offender" in several cases. Using this term in domain of offences never seems accurate, since such terms can be only used in field of criminology.

\section{Second: Encountering offences}

When a probable offence is discovered, an inspection team is submitted on behalf of FINRA to take the supervisory task for more investigations and the legal measures are taken by this institute by itself or by cooperation of the exchanges if necessary. If the desired case goes beyond the legal area of the FINRA, the desired case is submitted to SEC or other qualified authorities. This is other than the cases referred to SEC on the frauds on behalf of other units of FINRA.

\section{c. Offences}

One of the main elements of each society is the financial market and economic system of that society. Therefore, it has covered the criminal law with criminalization of behaviors disrupting the economics, social economic system, 
commerce, production and financial competition of business companies, stock exchange and so on. In fact, economy is one of the values supported by the legislators. As exchange offences are committed in stock market as a financial market, they can be regarded as financial crimes, which disrupt the economic system of society and hence, they can be supported by the legislator. Exchange offences can be classified to two groups of general or special groups. In the following, the said classes are discussed separately.

\section{First: General offences of stock exchange}

The concept of these crimes is that the domain of committing them is not limited to stock exchange despite to special crimes of exchange, but also these actions are criminalized in framework of general criminal law. Hence, the legislator has referred these offences in assumption of realization of stock exchange to general criminal law that is same Islamic penal code. The main crimes in this field can be betrayal of trust, carriage and use of a forged document and so on. As the discussion is focused on general crimes of exchange, they are discussed here in short.

\section{(a). Betrayal of trust}

In the capital market, the final information provided for the certain people of listed companies in stock market due to their legal authority or their supervisors such as supervisors of companies in stock exchange can be as borrowing a movable property to them. The holder of final information can be the trusted entity of the company and the stockholders of a company can be its owners. Now, if the holder of final information spends the borrowed property only for self or special people out of the association or only for a part of people in the group, it can be regarded as an example of betrayal of trust (Sarikhani, Monfared, \& Ali, 2016).

\section{(b). Forgery and using forged document and providing unreal information}

In regard with forging and using forged document, it should be explained that the criminal title has been explained generally in criminal law and on the other hand, article 47 of Stock Exchange law has analyzed that. Hence, on one hand, it can be regarded as general offence and on the other hand, it can be regarded as special offence. However, this study has considered that as a general crime.

Article 47 of Exchange law says that people who provide unreal information or forged documents to the exchange organization or use forged documents to provide reports subject to this law, they would be convicted to the 
punishments determined in Islamic Penal Code approved in June 1996. Based on this article, following criminal titles can be extracted: providing unreal information for the exchange organization, providing forged proofs to the exchange organization, confirmation of unreal information, confirmation of forged documents, using forged information, documents or proofs to provide reports subject to the Stock Exchange Law (Farzadi, 2009).

\section{(c). Manipulation and fraud in stock market}

In regard with manipulation and fraud and their relationship with fraud and offence, it should be explained that both of them could be regarded as fraud. Legislator has not defined fraud in exchange law and has just mentioned the examples. In addition, in foreign laws, fraud refers to any kind of unjust and rare behavior taken to gain profit (Gamer, 2004). Some types of fraud include price manipulation, fraud in accounting, fraud in public supply of companies (Eshtiagh, 2011).

Price manipulation is one types of fraud, which has criminal sanction in the regulations dominated on stock market. The aim by manipulation is any kind of activity that disrupts the freely function of market supply and demand and leads to creation of unreal prices and misconduct of exchange activists with the aim of gaining more profit or tolerating lower loss (Nobakht, 2008). At the present, in accordance with paragraph 3 of article 46 of Exchange Law of 2005, price manipulation is regarded as crime.

In Iran Exchange Law, in accordance with paragraph 3 of article 46, crime realization (market manipulation) needs realization of one of the 3 consequences predicted by law: creating a misleading look in the process of exchange transactions, creating false prices for the securities or misconducting entities to take exchange deals (Ghorbani and Bagheri, 2010; Zamani, 2008). Exchange Organization has defined market manipulation as a conscious action to encourage others to buy stock or change the price falsely or controlling the securities price using false deals or interference in freely function of supply and demand in stock exchange (Iran Stock Exchange, 2002). Moreover, it has been mentioned that market manipulation refers to activities, which may disrupt the free performance of market supply and demand in any way and lead to creation of false prices and false demonstration of stock market activities and ultimately; misconducting the market activists (Zamani, 2008). In Iran Law, stock exchange law has entrusted the activities causeing market manipulation to the custom. According to the mentioned, it could be found that market manipulation refers to committing a series of actions resulting in disruption of market balance and disruption of natural status of the market and creation of false prices for the 
securities. In US law, fraud has various types and some of them are discussed in the following:

[1]. Manipulation of stock price: the fraud is usually done in form of a series of organized operations and with combination of several other fraudulent actions and is controlled by some people. this type of fraud can be committed through different ways and by completely different instruments, which tend to find good opportunity to do their transactions or sell their stocks with high and false price or decline the price to have purchase in lowest price. The common points of all types of fraud is that the price of dealt stock is not a price caused by free and real feedback of effective factors in price and secondly; the manipulated price can pave the way for fraud of the offenders (Desire). At the America, encountering market manipulation has gained attention of legislator from long times ago; so that one of the reasons for establishment of market and securities commission in 1934 is regarded as an action to fight against market manipulation. Because of the measures taken in stock market of this country, the manipulation rate was declined in the USA and the major part of market manipulation was happened in OTC markets and regional markets (Agggrrwal and $\mathrm{Wu}$, 1918-2006). In US Law, to realize manipulation, 4 conditions should be provided: taking or leaving fraudulent act, intention of fraud, causality and unreal relation and unreality (Putnins, 2011; Amini et al, 2015). In fact, for market manipulation, the entity should have the ability to affect price on one hand and take the measures with the intention of fraud; the measures should affect stock price and the created status should be unreal and false status. Despite Iran and French legal system that use typical criterion to detect the manipulation, US law uses mostly subjective criterion (Amini et al, 2015) (Mobin, 2016).

[2]. Fraud in investment researches and consultation: in this kind of fraud, investment banks, brokers, bank investment units and similar institutes use their influence in organization analysis unit in bad way. Through this, they can delete or change negative points mentioned in reports of these units in their clients and can even make advice for investment in those countries.

[3]. Turnover deals: this type of fraud is specified to exchange brokers and happens when a broker takes various deals for a client and the main goal is not the profitability of the client, but also the main goal has been gaining higher wage by the broker. This kind of offence can happen in 
account of those clients, who have authorized the broker to take transaction based on personal recognition. If the broker takes unnecessary or loss making transactions to enhance the wage, he has committed this crime.

[4]. Fraud on groups affiliates: this kind of fraud is committed on the members of special groups, which are selected as victim on behalf of the offender. Such person becomes close to groups such as members of associations, churches, social groups and professional organizations and suggests opportunities to them and the suggestion is apparently private and is not offered to anyone else and claims that the offer has been just presented because of religious interests and charity or based on goodwill (Eshtiagh, 2011)..

\section{Second: Special offences of Stock Exchange}

This type of crime refers to the offences relevant to stock exchange, special area and is limited to the exchange and such crimes would never happen if there were no stock market.

\section{(a). Abuse of final information}

This kind of offence includes illegal use of this information by the holder of them to do transactions, which are forbidden. Therefore, some entities can take an advantage compared to others because of having access to the information, since people can make decision in field of stock exchange compared to others.

\section{(b). Disclosure of important information}

Proper decision-making in stock exchange is possible when the said information is on time, significant and understandable. Real nature of prices, rational prediction of the future process and generally the transparency and just nature of market is questioned. In fact, the main purpose by disclosure of information can make the subjectivity to provide justice in the market and more integration of the market. Moreover, improvement of market transparency can itself increase the competition among the market activists and can enhance the relations of market members and investors and ease the monitoring and enforcement of regulations (Management Research).

\section{(c). Disclosure and publishing final information}

Another offence happened on the axis of final information can be disclosing and publishing the information. As it is clear from the title of this type of crime, the aim is taking a measure, because of which the holder of final 
information discloses the information for ordinary people and pave the way for disclosure of them to gain profit. The holders of final information, due to latter part of paragraph 1 of article 46, have no right to publish the information. If the holder takes measure other than this under the title of disclosure of final information other than legal provisions; the person has committed crime. This type of crime has a major different with abuse of final information: only holder of final information have ability to commit such crime, since in accordance with paragraph 1, the only responsible person for final information is the person who is charged to save the final information due to the responsibility. Hence, it seems that if an ordinary person gains some information in special way and if publishes them, the person will not be prosecuted in accordance with article 46 (Farzadi, 2009).

\section{(d). Forging the title broker, broker/dealer or marketer}

Article 48 of Exchange law in paragraph 4 has discussed on criminalization of some behaviors in stock market. Paragraph 1 of same article is specified to the title broker, broker-dealer or marketer. Whereby the paragraph, every person taking any action to take measure like broker, broker/dealer or marketer without observance of regulations and getting permission or taking action to introduce himself under the mentioned titles, that person has committed crime and is convicted to said punishment in the beginning of article 48 .

\section{(e). Taking measure to publish notification for public supply of securities}

Every person, before taking measure to publish notification, should submit the demand for securities along with the declaration of registration of announcement to get the permission of public supply to the organization (article 22). After analysis of the demand for registration of securities and the attachments and adjusting them with the regulations, the organization takes measure to confirm the demand (article 23). In addition to the mentioned, publishing the announcement needs observance of instructions approved in line with note of article 22 of the law. Hence, if a person takes such measure without observance of the said regulations, he/she has committed crime (Farzadi, 2009).

\section{Analysis of criminal justice on exchange offences}

As criminal justice plays key role in procedure, here it is discussed in short. In commitment of all mentioned offences, the amount of financial damage is high and cannot be compared with other financial crimes. The committers of such offences are mainly from the white-collar and powerful people of the society (Mohseni, 2012). The exchange law has been satisfied by imprisonment and 
unexpected cash fine in this field regardless of the imposed damage and the obtained profit by the offender. In other countries, heavy punishments have been considered for the offenders of exchange. Maximum punishment for the deal based on final information in US is up to 20 years imprisonment and up to 5million dollars fine, which has been criminalized based on US Securities Exchange Act of 1934 (Securities Exchange Act of 1934). At the same time, in accordance with article 46 of Securities Exchange Act, the punishment of the offenders of market manipulation as one of the most important crimes is imprisonment from 3months to 1year and fine from 2-5 times of the profit obtained, the loss applied, or both punishments. Hence, compared to criminal sanctions of other countries, which are harder than Iran, the punishment predicted in Exchange Act is not preventive and is not suitable for this crime and it is necessary to intensify that (Monfared \& Ali, 1999)

In US law, punishment for violation of legal regulations is intense and compared to the punishments in Islamic Penal Code, it can be regarded as the imprisonment higher than degree 2. Compared to the corresponding punishment in Exchange Act for similar offence (paragraph 3 of article 49 in said act), the punishment is very hard. The hard punishment shows the proper recognition of crime in US law and understanding the consequences of such offences on the society.

It seems that the law should be amended in field of punishment for committing exchange offences with the approach of proportion of crime level and the punishment. With the existence of determining such grade of punishment for these people, the judge and judicial authority should consider some criteria in position of enforcement and select proper punishment based on the criteria. Considering conditions of the offence, the amount of loss imposed on the entity or society, considering the conditions of the offender, age, job and gender and family situation (Arie Freiberg, 2012) are the points, which should be considered by the judge to appoint the punishment. As alternative imprisonment punishment is determined based on articles 65-67 of new act for all offenders with punishment of up to 1-year imprisonment and as majority of exchange offences (mostly offences inserted in article 46 and 49), those are in the group of offences with up to 1-year imprisonment (Javanmardi \& Masoudi Magham, 2017).

\section{Exchange procedure}

Here, the items on type of procedure and the process are discussed. Hence, it is necessary at the first to specify the public or private nature of such lawsuits. 
Public lawsuit or same criminal prosecution of offender is presented and prosecuted by the court and as a representative of the society. Prosecutor is in top of the court and based on article 11 of Criminal Procedure, prosecution of offender and presenting lawsuit, from public dignity aspect, is the responsibility of prosecutor (Khaleghi, 2015).

Private lawsuit is the lawsuit of a person, who has gained loss from the action of the criminal against the public lawsuit (Langerudi \& Jafar, 2003). Making loss to public order makes this right for the society to present the public lawsuit by means of the prosecutor to ask for punishment of the offender by impartial authority. Making loss for the right of entity or entities makes this right for them to not only ask for prosecution and punishment through submitting complaint to prosecution authority, but also present private lawsuit in legal court to ask for compensation of imposed losses (Khaleghi, 2015).

\section{First: Iran}

In regard with the authority and the procedure of these criminal examples, article 52 of Exchange Act says: "the organization is charged to collect the documents relevant to offences subject to this act and announce them to beneficiary legal courts and prosecute the case due to subject. If entities have gained loss as a result of said offences, the injured party can refer to legal authorities to compensate the losses and submit the petition for loss compensation".

\section{Second: America}

The procedure in America is taken by FINRA. FINRA presents the arbitration services for all member exchanges of FINRA, which have selected the arbitration way through arbitration agreements. In addition to using arbitration, the investors can submit their complaint to the prosecution unit of FINRA in case of occurrence of fraud, forgery and illegal activities. After presenting the complaint and taking required investigations, if the fraud is proved, reprimand, fine and suspension of the offender is taken.

\section{CONCLUSIONS}

With the existence of measures taken in this field such as approving new regulations and even referral to public penal codes and constitution to organize the capital market, the mentioned market still faces various problems. On the other hand, despite to complete criminal regulations approved in field of exchange offences, the gap of existence of transparent and adequate procedure 
for market nature is tangible. The qualification of specialized authorities of the market is limited to regulation offences and disputes of market activists and procedure of the offences committed in this field can be the responsibility of judicial authorities. However, the said authorities have big portion in organizing the market disputes and there is necessary to have accurate and comprehensive management for the qualifications of the procedure elements for market disputes such as qualification of board and the exchange board subject to article 43 of Securities Exchange Act for welfare of the clients and the certainty of the law. Another point is the binding and certain nature of arbitration votes, which is not accurate. This is because; although the members of the board can be complete collection of experienced and specialized people in field of legal and economic issues and there is rarely possible to make mistake in procedure and issuance of order, this is in contradiction with the legal system of Iran, which is law-based system. In spite of the US as a procedure-based country, the arbitration is completely true and based on regulations of that country. However, due to the heavy financial cases prosecuted in this board, it is rational to make it possible to appeal minimum votes for costs higher than certain cost. Arbitration authority in the capital market of US means general meaning of arbitration and as appointed arbitrators have required experience in cases, the authority is adjusted with the regulations of the market. In this regard, the experiences of this country can be used as a successful country in this field.

\section{REFERENCES:}

Desire, W. (t.thn.). A Look at the Legal Order of the US Securities Market. Newspaper Number: 2426, August 16, 90, Newsletter: 412387.

Eshtiagh, V. (2011). A Look At The Legal Order Of The Us Securities Market. Newspaper Number: 2426, News No:412387.

Farzadi, M. (2009). Criminal Protection Of The Securities Market. Qom: Master's Degree In Criminal Law And Criminology, University Of Qom.

(t.thn.). Instructions of the Securities and Exchange Brokers Association Committee .

Javanmardi, M., \& Masoudi Magham, A. (2017). The Influence Of Exchange Offenses On Innovations In Islamic Penal Code. Quarterly Stock Exchange, 111-137.

Kadkhodaei, H. (1999). Principles Of Capital Market Regulations. Tehran: Central Bank Of Iran. 
Karimi, Z. (2017). A Comparison Of Brokers' Violations Of Stock Exchange Law And Securities Market Law. Journal Of The Capital Market Of Iran.

Khaleghi, A. (2015). The Criminal Procedure Code. Tehran: Ganj Danesh Publications.

Langerudi, J., \& Jafar, M. (2003). Terminology Of Law. Tehran: Ganj Danesh Publications.

Management Research. (t.thn.). Development and Islamic Studies of Tehran Stock Exchange Organizatio. Information Disclosure Policy and Requirements.

Mehrabi Pour, L. (2009). A Look At The Activities Of The Jury. Stock Exchange.

Mobin, H. (2016). Civil Liability Due To Manipulation Of The Securities Market. Bori Securities Quarterly.

Monfared, M., \& Ali, G. (1999). Comparative Study Of Market Dispute Settlement Mechanisms. Tehran: Tehran Stock Exchange Information Company.

Noorani, M. S., \& Eyvazi, A. (2016). types of lawsuits and procedures in Iran and US capital markets. comparative law studies, 1(7).

Sarikhani, A. A., Monfared, M., \& Ali, G. (2016). Analysis Of Jurisprudential And Legal Principles Of Crimes Related To Final Information In The Stock Market. Quarterly Bulletin.

Securities Exchange Act of 1934, S. 